\title{
En-face parameters change after orthodontic treatment of Class II malocclusion
}

\author{
Jovana Milutinović, Nenad Nedeljković \\ University of Belgrade, School of Dental Medicine, Department of Orthodontics, Belgrade, Serbia
}

\begin{abstract}
SUMMARY
Introduction The aim was to evaluate the difference in en-face anthropometric facial parameters and proportions of patients with Class II malocclusion, before and after orthodontic treatment as well as changes in linear parameters and facial proportions and their deviation from ideal values.

Material and method In this study, en-face photographs before and after the treatment of 50 Class II malocclusion patients were used. Patients were divided in two groups; first group comprised 25 patients treated with multibracket appliance with extractions, and second group included 25 patients treated without extractions, using fixed functional Herbst and multibracket appliance. On each and every photo before and after the treatment facial points and lines were drawn, and linear parameters were determined, based on those markers.

Results showed change in anthropometric parameters in both groups of patients. Statistically significant difference was found for parameters in the middle and lower facial third. Facial proportions changed after the treatment in both groups and they approached ideal values and golden proportion 1:1.618 in the lower facial third.

Conclusion Patients with Class II, division 1 malocclusion, deviate from an ideal set of proportions, particularly in the lower facial third. After the orthodontic treatment, anthropometric parameters in the lower facial third were approaching ideal values.
\end{abstract}

Keywords: Class II Malocclusion; anthropometry; facial proportions

\section{INTRODUCTION}

Facial esthetics evaluation has long history of development. In the last century, one of the first ways to measure facial parameters was actually the measurement of soft tissue profile characteristics. Soft tissue profile parameters were measured on cephalograms, while enface parameters were not taken into consideration due to poor visibility on anterior and posterior x-rays of head. These $\mathrm{x}$-rays are indicated for skeletal, rather than dental structures analysis, in case of facial asymmetry. However, they were not the choice for soft tissue en-face parameter measurements. Although soft tissue analyses, known and described by authors in the last century, found their use in orthodontic diagnostics, they cannot be used for determining facial beauty in broader concept [1]. In the past, several soft tissue analyses were developed for measuring facial parameters $[2,3]$. These out-of-date analyses have not been combined with clinical assessment and none of them was used for important facial elements evaluation. Just recently, facial balance, beauty diagnosis and treatment planning are improved with combined clinical analysis and soft tissue cephalometric analysis [4].

At this moment, cephalometric three-dimensional soft tissue analysis, that would be useful for facial beauty guidelines determination, do not exist. Orthodontic treatment that corrects dentofacial anomaly (dental, skeletal, soft tissue anomaly) does not change facial appearance, therefore the answer lies in appearance comparison (be- fore and after the treatment) $[5,6]$. For that reason, it is necessary to measure en-face parameters on facial photographs before and after the orthodontic treatment, in terms of precise and highly justifiable facial perception change $[7,8]$.

Facial harmony is associated with golden proportions. However, one cannot be assured that achieving golden proportions would change facial beauty perception. Several studies confirmed proportions influence in facial attractiveness; these results need to be taken with caution in terms of orthodontic treatment only $[9,10,11]$.

The aim of this study was to determine the difference in en-face anthropometric facial parameters and proportions in patients with Class II malocclusion, before and after orthodontic treatment. Using en-face facial photographs, deviation from ideal proportions, especially in the lower facial third was determined.

\section{MATERIALS AND METHODS}

In this study en-face photographs of 50 Class II patients before and after the treatment were used. Patients were divided in two groups; first group of 25 patients was treated with extractions using multibracket appliance - Figure 1a, and second group, 25 patients were treated with the cast splint Herbst appliance followed by multibracket appliances treatment - Figure $1 b$. On each and every photo before and after the treatment facial points and lines were 

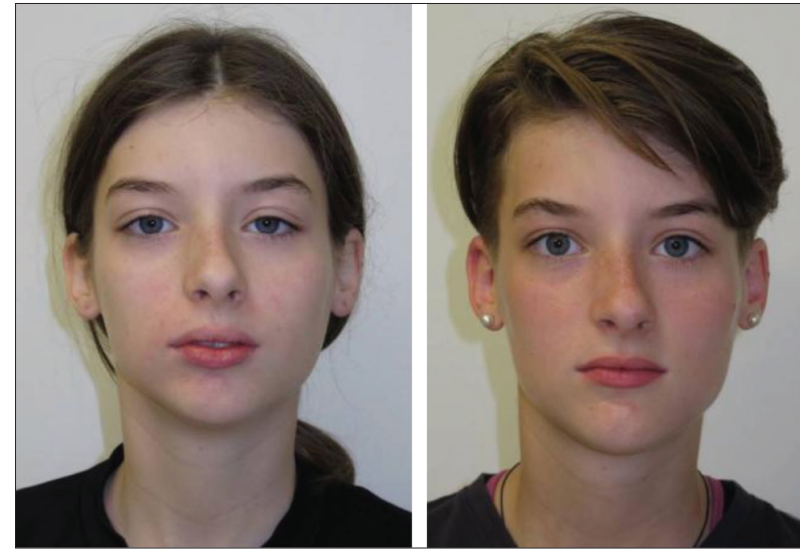

Figure 1a. Before and after treatment photographs of the patient treated with extractions

Slika 1a. Fotografije pacijenta pre i posle terapije (ekstrakciona metoda)

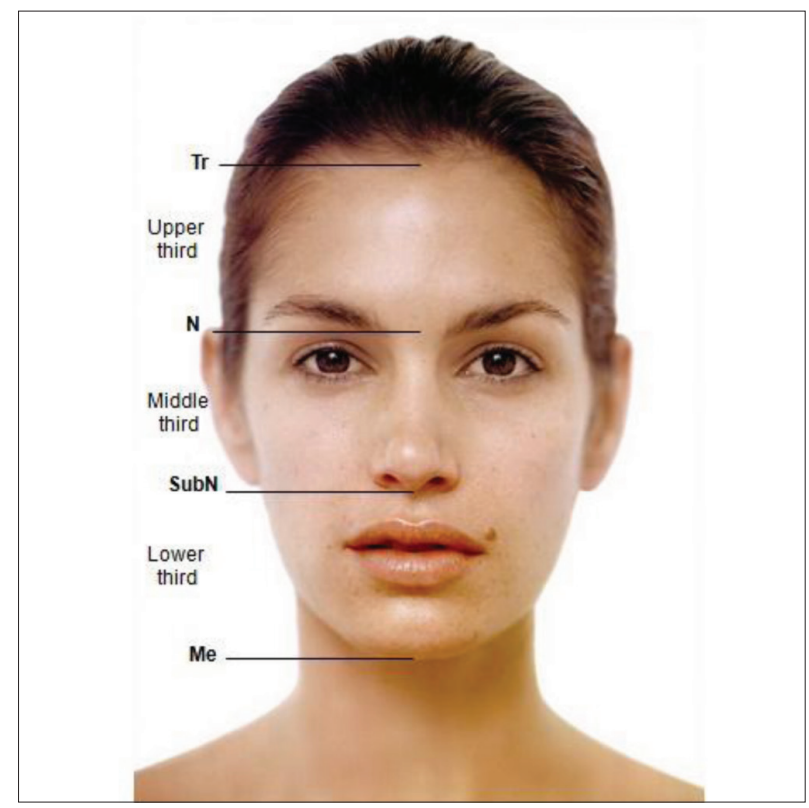

Figure 2. Division of the face into horizontal thirds Slika 2. Podela lica na horizontalne trećine

drawn, and linear parameters were determined, based on those markers.

\section{Facial markers, measured on photographs are} as follows:

Ch (cheilion) - the point on the corner of the mouth

LC (lateral canthus) - the point on the lateral corner of the eye

Ln (lateral nose) - the outer edge of the nostril

Lchk (lateral cheek) - the most lateral point on the cheek

Ts (temporal soft tissue) - the most lateral point of eyebrows

$\operatorname{Tr}$ (trichion) - highest point of the forehead

$\mathrm{N}$ (nasion) - the point between upper and middle third of the face

Sn (subnasale) - the point where lowest edge of the nose and upper lip merge

sto (stomion) - the point where the upper and lower lip merge

Me (menton) - the lowest point on the chin.

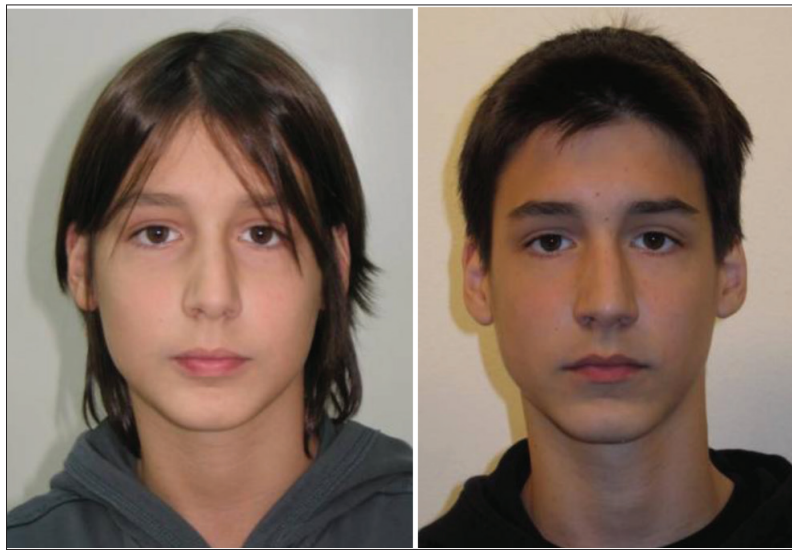

Figure 1b. Before and after treatment photographs of the patient treated without extractions

Slika 1b. Fotografije pacijenta pre i posle terapije (neekstrakciona metoda)

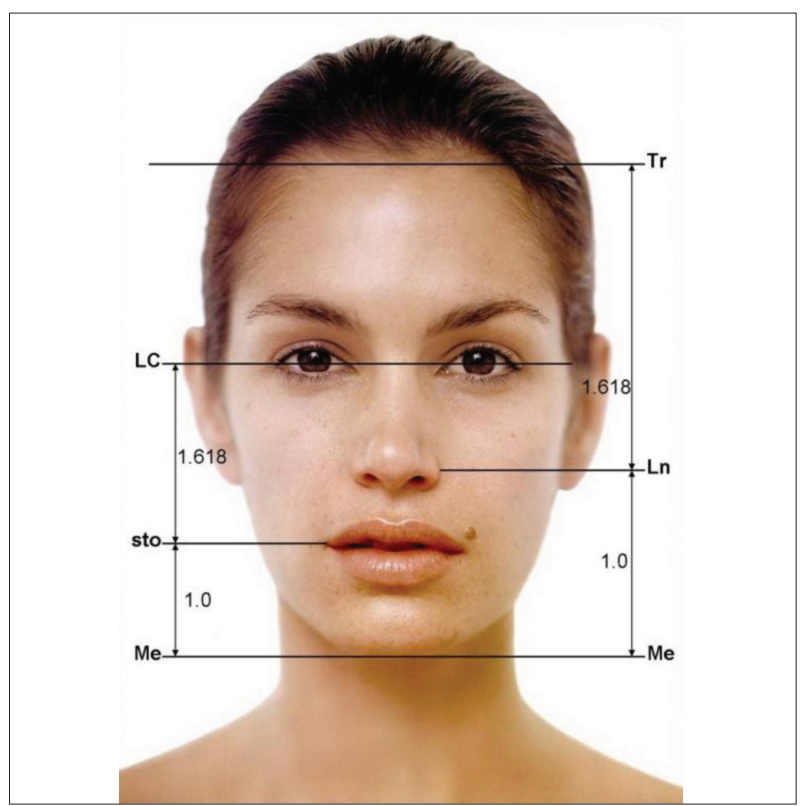

Figure 3. Lengths of the face and set of ideal proportions Slika 3. Proporcije linearnih parametara

On the photographs, the following parameters were measured:

I. The horizontal thirds of the face (Figure 2):
1) Upper third: Tr-N
2) Middle third: N-subN
3) Lower third: subN-Me.

II. Lengths - proportions (Figure 3):
1) Me-sto
2) sto - LC
3) $\mathrm{Me}-\mathrm{Ln}$
4) $\mathrm{Ln}-\mathrm{Tr}$.

III. Dimensions of the face (Figure 4):

1) Length (height) of the face (Tr-Me)

2) Width of the face (lchk r-lchk l).

After determining facial markers and connecting them into appropriate lengths, proportions were measured. There are ideal proportions for each of parameters, so 


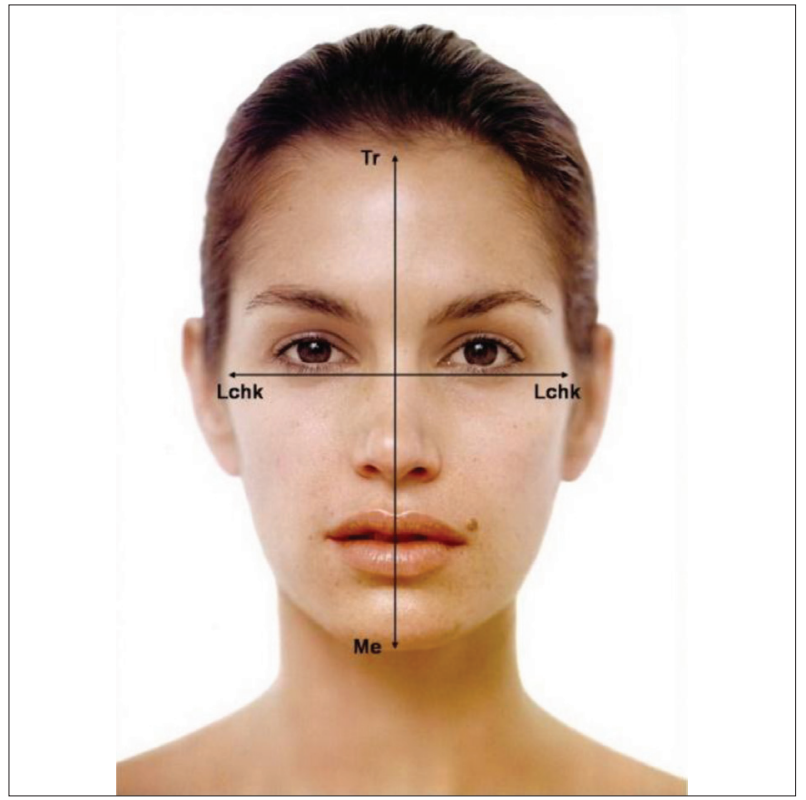

Figure 4. Dimensions of the face - height and width Slika 4. Dimenzije lica - dužina i širina

that the actual length of various parameters does not play role and errors are minimized.

Horizontal thirds of the face should be equal, forehead, nose and jaw thirds should be the same length on each photo individually, their actual length is not important, but only their relationship (Figure 2).

Upper third of the jaw third, the distance between Subnasale and stomion should be $1 / 3$ of the total length of the jaw third, ie. distance between Subnasale - Menton (Figure 5).

The distance Menton - stomion and stomion - Lateral Canthus should be 1 to 1.618 (Figure 3).

The distance Menton - lateral nose and Lateral nose Trichion should be 1 to 1.618 (Figure 3).

If the width of the face (distance between two points lateral cheek (lchk)) is 1 , the length of the face (distance between points Trichion and Menton) should be 1.618 (Figure 5).

\section{RESULTS}

The results are presented in Tables 1 and 2. Parameter change after the orthodontic treatment in both groups is presented in Table 1. Statistically significant difference was found for parameters of the middle and lower third (N-subN and subN-Me), in both groups. Their ratio changed and in the first group it was 0.9 while in the second group it was 0.92 .

The length parameters and their ratio are presented in Table 2. Parameters Me-Ln and Tr-Me showed significant change after the treatment $(\mathrm{Sig}<0.01)$. When we compare the ratio of middle and lower third of the face, it can be noted that before the therapy it was 1.1 (length $\mathrm{N}$ - subN was $46.77 \mathrm{~mm}$, length of subN-Me was $52.20 \mathrm{~mm}$ ), while after the treatment this ratio became 0.9 (length $\mathrm{N}$ - subN was $43.72 \mathrm{~mm}$ and the length of subN-Me was $48.44 \mathrm{~mm}$ ).

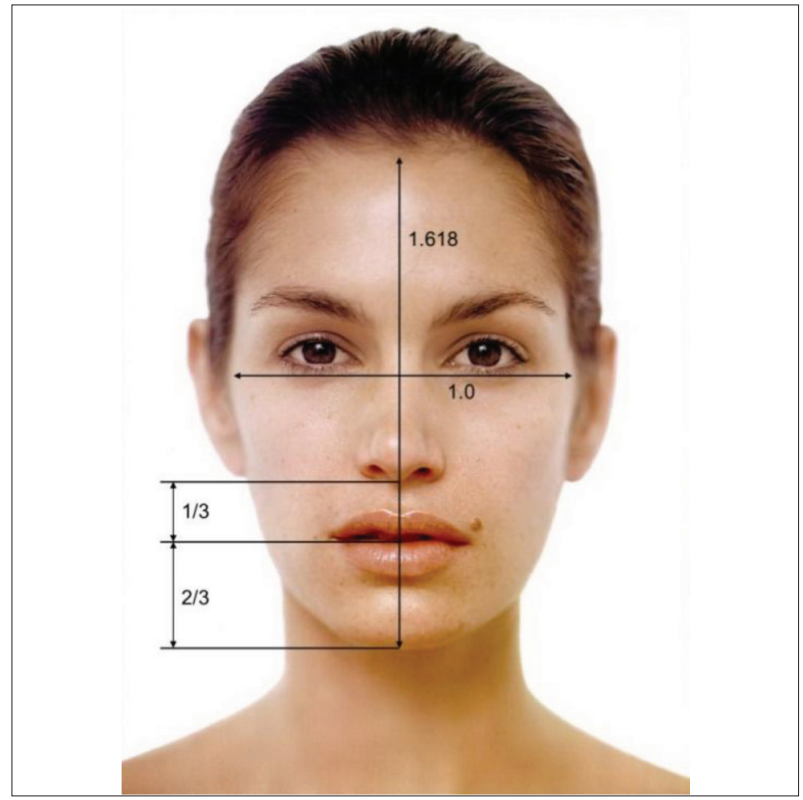

Figure 5. Set of ideal proportions - guidelines Slika 5. Idealne proporcije - smernice

In the first group of patients, the ratio of Me-Ln and LnTr length before the treatment was 1:1.36 (length Me-Ln was $61.93 \mathrm{~mm}$ and length $\mathrm{Ln}$ - $\mathrm{Tr}$ was $84.38 \mathrm{~mm}$ ) while after the treatment this ratio was 1:1.5 (length Me-Ln was $55.71 \mathrm{~mm}$ and length $\mathrm{Ln}-\mathrm{Tr}$ was $83.76 \mathrm{~mm})$. In the second group of patients, the ratio of these two parameters before the treatment was 1.45 (length Me-Ln was $48.72 \mathrm{~mm}$ and length Ln-Tr was $70.72 \mathrm{~mm}$ ). After the treatment this ratio changed at 1.62 (length Me-Ln was $48.57 \mathrm{~mm}$ and length Ln-Tr was $78.77 \mathrm{~mm})$.

\section{DISCUSSION}

Analysis of facial parameters and their comparison with standard-average values are necessary in different fields of medicine and dentistry that are able to change facial characteristics in different ways $[12,13,14]$. Some of the specialties like plastic surgery, maxillofacial surgery, orthodontics and prosthodontics are able to perform these kinds of changes. Assumingly, it is important to balance the outcome of the treatment with patient's expectations, as well their family and friends. Individual beauty assessments and variations in broader opinion about beauty concept, which is highly dependent of modern trends and fashion, are subject of investigations of various authors. [15] Therefore, orthodontists and surgeons have to be united when it comes to objective clinical goals about patient's appearance improvement $[16,17]$.

In our research en-face parameters were measured. They indicate facial symmetry and division of the face into various proportions and regions, and compatibility with the set of ideal proportions. As it was already mentioned, beauty is very individual; it lies in the eye of observer, and it is difficult to measure and compare it. Therefore, quantitative and numeric comparison between the two groups of patients was not done [18]. 
Table 1. Horizontal thirds of the face

Tabela 1. Horizontalne trećine lica i njihov odnos

\begin{tabular}{|c|c|c|c|c|c|c|c|c|}
\hline \multirow[t]{3}{*}{\begin{tabular}{|l|} 
Statistical Parameters \\
Statistički parametri
\end{tabular}} & \multicolumn{8}{|c|}{$\begin{array}{l}\text { EXTRACTION } \\
\text { VAĐENJE ZUBA }\end{array}$} \\
\hline & \multicolumn{2}{|c|}{$\operatorname{Tr}-\mathrm{N}(\mathrm{mm})$} & \multicolumn{2}{|c|}{$\mathrm{N}$-subN (mm) } & \multicolumn{2}{|c|}{ subN-Me $(\mathrm{mm})$} & \multicolumn{2}{|c|}{ subN-sto $(\mathrm{mm})$} \\
\hline & $\begin{array}{l}\text { Before } \\
\text { Pre }\end{array}$ & $\begin{array}{l}\text { After } \\
\text { Posle }\end{array}$ & $\begin{array}{l}\text { Before } \\
\text { Pre }\end{array}$ & $\begin{array}{l}\text { After } \\
\text { Posle }\end{array}$ & $\begin{array}{l}\text { Before } \\
\text { Pre }\end{array}$ & $\begin{array}{l}\text { After } \\
\text { Posle }\end{array}$ & $\begin{array}{l}\text { Before } \\
\text { Pre }\end{array}$ & $\begin{array}{l}\text { After } \\
\text { Posle }\end{array}$ \\
\hline $\begin{array}{l}\text { Mean } \\
\text { Srednja vrednost }\end{array}$ & 47.54 & 47.31 & 46.77 & 43.72 & 52.20 & 48.44 & 18.08 & 16.79 \\
\hline $\begin{array}{l}\text { St. Dev. } \\
\text { Standardna devijacija }\end{array}$ & 4.01 & 4.09 & 3.74 & 1.67 & 3.23 & 3.24 & 2.58 & 2.46 \\
\hline $\begin{array}{l}\text { Significance } \\
\text { Značajnost }\end{array}$ & \multicolumn{2}{|c|}{0.86} & \multicolumn{2}{|c|}{0.00} & \multicolumn{2}{|c|}{0.00} & \multicolumn{2}{|c|}{0.13} \\
\hline \multicolumn{5}{|c|}{ Ratio/Odnos N-subN / subN-Me } & 1.1 & 0.9 & & \\
\hline \multirow[t]{2}{*}{$\begin{array}{l}\text { Statistical Parameters } \\
\text { Statistički parametri }\end{array}$} & \multicolumn{8}{|c|}{$\begin{array}{l}\text { NON EXTRACTION } \\
\text { BEZ VAĐENJA ZUBA }\end{array}$} \\
\hline & $\begin{array}{l}\text { Before } \\
\text { Pre }\end{array}$ & $\begin{array}{l}\text { After } \\
\text { Posle }\end{array}$ & $\begin{array}{l}\text { Before } \\
\text { Pre }\end{array}$ & $\begin{array}{l}\text { After } \\
\text { Posle }\end{array}$ & $\begin{array}{l}\text { Before } \\
\text { Pre }\end{array}$ & $\begin{array}{l}\text { After } \\
\text { Posle }\end{array}$ & $\begin{array}{c}\text { Before } \\
\text { Pre }\end{array}$ & $\begin{array}{l}\text { After } \\
\text { Posle }\end{array}$ \\
\hline $\begin{array}{l}\text { Mean } \\
\text { Srednja vrednost }\end{array}$ & 40.01 & 46.01 & 36.33 & 39.23 & 43.39 & 42.07 & 13.78 & 14.57 \\
\hline $\begin{array}{l}\text { St. Dev. } \\
\text { Standardna devijacija }\end{array}$ & 3.41 & 3.62 & 4.79 & 5.87 & 4.47 & 4.77 & 1.58 & 1.99 \\
\hline $\begin{array}{l}\text { Significance } \\
\text { Značajnost }\end{array}$ & \multicolumn{2}{|c|}{0.60} & \multirow{2}{*}{\multicolumn{2}{|c|}{0.00}} & \multicolumn{2}{|c|}{0.00} & \multirow{2}{*}{\multicolumn{2}{|c|}{0.20}} \\
\hline Ratio/Odnos N-subN / & & & & & 1.1 & 0.92 & & \\
\hline
\end{tabular}

Table 2. Linear parameters and their relation to ideal set of proportions

Tabela 2. Linearni parametri i njihov odnos prema idealnim proporcijama

\begin{tabular}{|c|c|c|c|c|c|c|c|c|c|c|c|c|}
\hline \multirow[t]{3}{*}{$\begin{array}{l}\text { Statistical Parameters } \\
\text { Statistički parametri }\end{array}$} & \multicolumn{12}{|c|}{$\begin{array}{l}\text { EXTRACTION } \\
\text { VAĐENJE ZUBA }\end{array}$} \\
\hline & \multicolumn{2}{|c|}{ Me-sto $(\mathrm{mm})$} & \multicolumn{2}{|c|}{ Sto-LC (mm) } & \multicolumn{2}{|c|}{$\mathrm{Me}-\mathrm{LN}(\mathrm{mm})$} & \multicolumn{2}{|c|}{$\mathrm{LN}-\operatorname{Tr}(\mathrm{mm})$} & \multicolumn{2}{|c|}{$\operatorname{Tr}-\mathrm{Me}(\mathrm{mm})$} & \multicolumn{2}{|c|}{ Lchk-Ichk (mm) } \\
\hline & $\begin{array}{l}\text { Before } \\
\text { Pre }\end{array}$ & $\begin{array}{l}\text { After } \\
\text { Posle }\end{array}$ & $\begin{array}{c}\text { Before } \\
\text { Pre }\end{array}$ & $\begin{array}{l}\text { After } \\
\text { Posle }\end{array}$ & $\begin{array}{l}\text { Before } \\
\text { Pre }\end{array}$ & $\begin{array}{l}\text { After } \\
\text { Posle }\end{array}$ & $\begin{array}{l}\text { Before } \\
\text { Pre }\end{array}$ & $\begin{array}{l}\text { After } \\
\text { Posle }\end{array}$ & $\begin{array}{l}\text { Before } \\
\text { Pre }\end{array}$ & $\begin{array}{l}\text { After } \\
\text { Posle }\end{array}$ & $\begin{array}{l}\text { Before } \\
\text { Pre }\end{array}$ & $\begin{array}{l}\text { After } \\
\text { Posle }\end{array}$ \\
\hline \begin{tabular}{|l} 
Mean \\
Srednja vrednost
\end{tabular} & 34.23 & 31.69 & 52.74 & 52.04 & 61.93 & 55.71 & 84.38 & 83.76 & 146.51 & 139.46 & 99.08 & 96.03 \\
\hline $\begin{array}{l}\text { St. Dev. } \\
\text { Standardna devijacija }\end{array}$ & 4.79 & 4.87 & 3.51 & 2.91 & 6.80 & 3.93 & 5.23 & 4.87 & 2.62 & 8.89 & 13.81 & 11.52 \\
\hline $\begin{array}{l}\text { Significance } \\
\text { Značajnost }\end{array}$ & \multicolumn{2}{|c|}{0.12} & \multicolumn{2}{|c|}{0.52} & \multicolumn{2}{|c|}{0.00} & \multicolumn{2}{|c|}{0.00} & \multicolumn{2}{|c|}{0.71} & \multicolumn{2}{|c|}{0.48} \\
\hline \multicolumn{9}{|c|}{ Ratio/Odnos Me-Ln / Ln- Tr = $1: 1.618$} & $1: 1.36$ & $1: 1.5$ & & \\
\hline \multirow[t]{2}{*}{\begin{tabular}{|l|} 
Statistical Parameters \\
Statistički parametri \\
\end{tabular}} & \multicolumn{12}{|c|}{$\begin{array}{l}\text { NON EXTRACTION } \\
\text { BEZ VAĐENJA ZUBA }\end{array}$} \\
\hline & $\begin{array}{c}\text { Before } \\
\text { Pre }\end{array}$ & $\begin{array}{l}\text { After } \\
\text { Posle }\end{array}$ & \begin{tabular}{|c} 
Before \\
Pre
\end{tabular} & $\begin{array}{l}\text { After } \\
\text { Posle }\end{array}$ & $\begin{array}{l}\text { Before } \\
\text { Pre }\end{array}$ & $\begin{array}{l}\text { After } \\
\text { Posle }\end{array}$ & $\begin{array}{c}\text { Before } \\
\text { Pre }\end{array}$ & $\begin{array}{l}\text { After } \\
\text { Posle }\end{array}$ & $\begin{array}{l}\text { Before } \\
\text { Pre }\end{array}$ & $\begin{array}{l}\text { Afte } \\
\text { Pos }\end{array}$ & $\begin{array}{l}\text { Before } \\
\text { Pre }\end{array}$ & $\begin{array}{l}\text { After } \\
\text { Posle }\end{array}$ \\
\hline \begin{tabular}{|l} 
Mean \\
Srednja vrednost
\end{tabular} & 29.67 & 27.53 & 43.50 & 47.40 & 48.72 & 48.57 & 70.72 & 78.77 & 119.72 & 127. & 87.33 & 91.93 \\
\hline $\begin{array}{l}\text { St. Dev. } \\
\text { Standardna devijacija }\end{array}$ & 5.83 & 5.02 & 4.84 & 9.49 & 7.28 & 7.39 & 6.59 & 3.44 & 7.18 & 9.2 & 7.03 & 5.42 \\
\hline \begin{tabular}{|l|} 
Significance \\
Značajnost
\end{tabular} & \multicolumn{2}{|c|}{0.25} & \multicolumn{2}{|c|}{0.13} & \multicolumn{2}{|c|}{0.00} & \multirow{2}{*}{\multicolumn{2}{|c|}{0.00}} & \multicolumn{2}{|r|}{0.95} & \multirow{2}{*}{\multicolumn{2}{|c|}{0.09}} \\
\hline Ratio/Odnos Me-Ln / & $=1: 1.6$ & & & & & & & & $1: 1.45$ & $1: 1$. & & \\
\hline
\end{tabular}

Upper, middle and lower facial third should be, in case of harmonically balanced face, approximately equal (ratio 1:1). Lower facial third is divided with line that goes through the point stomion, in upper and lower part, and their ratio should be 1:2 [19].

In the group of patients who had some teeth extracted, statistically significant difference for parameters of middle and lower third was found. As mentioned earlier ratio is more important than the actual numbers. Not taking into consideration values in millimeters but change in relation between parameters we can see slight increase in vertical dimension of lower facial third after finished orthodontic treatment. The reason and explanation can be found in changing the parameters of vertical growth, and increasing vertical dimension due to the application of Class II intermaxillary elastics. However, observing these values and comparing them with the set of ideal proportions, it is noticeable that the ratio between these proportions and their closeness to ideal values did not significantly change, so that difference cannot be described as facial attractiveness change. Nevertheless, the change is visible to clinicians and in the eye of observer. Shell et al. [20] came to the same conclusion when they compared ideal proportions in Class II patients treated with activator during growth, and after the period of active growth, with multibracket appliance with or without orthognatic surgery. They compared re- 
lation between ideal proportions and facial attractiveness perception and found that although orthodontic treatment changed facial appearance, it is debatable to what extent that change means achievement of ideal proportions [21].

In the group of patients treated without extractions comparing the parameters of the horizontal division of the face into equal thirds, statistically significant difference was found for the parameter Tr-N.As the upper third of the face significantly change, it is important to identify and interpret newly established relationship of face division into thirds and whether it affects patient's perception in accordance with possible approach to golden proportions. In this group of patients, similar findings about changes in relationship of the lower and middle thirds of face on one side and upper facial third on the other side were found. The original ratio was reduced from 1.1 to 0.92 , which was explained as slight change in vertical dimension of the lower third of the face [22].

Ratio between linear parameters in ideal proportions should be, in numerical terms, 1:1.618. Linear parameter of Me-Ln and Ln-Tr before the treatment was 1:1.36, while after the treatment that relation was 1:1.5. The ideal ratio is $1: 1.618$, and after the treatment the ratio came closer to this value because the parameter Me-Ln in the lower facial third changed.

Even though the parameter Tr-Me (the length of the face) significantly changed after the orthodontic treatment, the ratio between facial length and width that should be close to golden ratio of 1 to 1.618 did not change much. This ratio between the facial length (Tr-Me) and width (lchk-lchk) before treatment was 1.47 and after the treatment it was 1.45. As these values talk more about the broader aspect of enface look and can be associated with the shape of the face, it is expected that this segment will not be much changed after the treatment.

In the group of facial length parameters defined by ideal proportions, in patients treated with fixed functional appliance without extraction, statistically significant difference was observed for the parameter Ln-Tr, which was in golden proportion with the parameter Me-Ln. These two parameters had ratio 1.45 before the treatment, while after the treatment this ratio changed to 1.62 that is ideal relationship between these two parameters. Therefore, in this group of patients ideal ratio was achieved between these two parameters, one of which is directly related to the outcome of orthodontic treatment, new position of chin and Menton (the lowest point on the chin). Our results are consistent with the research of Scolozzi et al. [23] who also reached ideal ratio after completing treatment for the same parameter in the lower third of the face.

Baker et al. [24] performed study about relation between ideal facial proportions and attractiveness perception after orthodontic and surgical treatment taking into consideration facial entities that influence facial beauty concept in general. They used a questionnaire and in results reported significant improvement of facial attractiveness after the treatment, although without strong connection with ideal values. They suggested this analysis to be used only as addition to cephalometric and anthropometric analysis.
Expectedly, Class II malocclusion treatment had limited influence on en-face facial parameters, and consequently achieving ideal values. However, significant changes occurred in the soft tissue profile, so that the measurement of these parameters on the profile photographs, as shown in many studies, is an indispensable supplement to complete analysis of facial soft tissue parameters [25].

\section{CONCLUSION}

After anthropometric measurement of linear parameters and proportions, it can be concluded that patients with Class II, division 1 malocclusion, deviate from an ideal set of proportions, particularly in the lower facial third. After the orthodontic treatment, these parameters were approaching the set of ideal values, in both groups of treated patients (with and without extractions).

\section{REFERENCES}

1. Medici FE, Martins MV, dos Santos da Silva MA, Castilho JC, de Moraes LC, Gil CT. Divine proportions and facial esthetics after manipulation of frontal photographs. World J Orthod. 2007; 8(2):103-8. [PMID: 17580503]

2. Bashour M. History and current concepts in the analysis of facial attractiveness. Plast Reconstr Surg. 2006; 118(3):741-56. [DOI: 10.1097/01.prs.0000233051.61512.65] [PMID: 16932186]

3. Baysal A, Uysal T. Dentoskeletal effects of Twin Block and Herbst appliances in patients with Class II division 1 mandibular retrognathy. Eur J Orthod. 2014; 36 (2):164-72. [DOI: 10.1093/ejo/cjt013]

4. Wylie GA, Fish LC, Epker BN. Cephalometrics: a comparison of five analyses currently used in the diagnosis of dentofacial deformities. Int J Adult Orthod Orthog Surg. 1987; 2(1):15-36. [PMID: 3469281]

5. Basciftci F, Uysal T, Buyukerkmen A, Demir A. The influence of extraction treatment on Holdaway soft-tissue measurements. Angle Orthod. 2004; 74(2):167-73. [DOl: 10.1043/0003-3219(2004)074<0167:TI OETO> 2.0.CO;2] [PMID: 15132442]

6. Meyer AH, Woods MG, Manton DJ. Maxillary arch width and buccal corridor changes with orthodontic treatment. Part 2: Attractiveness of the frontal facial smile in extraction and nonextraction outcomes. Am J Orthod Dentofacial Orthop. 2014; 145(3):296-304. [DOI: 10.1016/j.ajodo.2013.10.019] [PMID: 24582021]

7. Edler R, Agarwal P, Wertheim D, Greenhill D. The use of anthropometric proportion indices in the measurement of facial attractiveness. Eur J Orthod. 2006; 28(3):274-81. [DOl: 10.1093/ejo/cji098] [PMID: 16415084]

8. Ferrario VF, Sforza C, Miani A, Tartaglia G. Craniofacial morphometry by photographic evaluations. Am J Orthod Dentofacial Orthop. 1993; 103(4):327-37. [DOI: 10.1016/0889-5406(93)70013-E] [PMID: 8480698]

9. Milutinović J, Zelić K, Nedeljković N. Evaluation of Facial Beauty Using Anthropometric Proportions. Sci W J. 2014; e1-e8. [DOI: 10.1155/2014/428250]

10. Rossetti A, De Menezes M, Rosati R, Ferrario VF, Sforza C. The role of the golden proportion in the evaluation of facial esthetics. Angle Orthod. 2013; 83(5):801-8. [DOI: 10.2319/111812-883.1] [PMID: 23477386]

11. Sforza C, Laino A, D'Alessio R, Grandi G, Tartaglia GM, Ferrario VF. Soft-tissue facial characteristics of attractive and normal adolescent boys and girls. Angle Orthod. 2008; 78(5): 799-807. [DOI: 10.2319/091207-431.1] [PMID: 18298221]

12. Epker BN. 1992. Adjunctive esthetic surgery in the orthognathic surgery patient. In McNamara JA, Carlson DS, Ferrara A (eds). Esthetics and the treatment of facial form. Monograph No 28, Craniofacial 
Growth Series, Center for Human Growth and Development, University of Michigan Ann Arbor, 187-216.

13. LaHaye MB, Buschang PH, Alexander RG, Boley JC. Orthodontic treatment changes of chin position in Class II Division 1 patients. Am J Orthod Dentofacial Orthop. 2006; 130 (6): 732-741.

14. McNamara JA, Brust EW, Riolo ML. Soft tissue evaluation of individuals with an ideal occlusion and well-balanced face. Angle Orthod. 1999; 70(3):200-7.

15. Proffit WR, Fields HW, Sarver DM. Contemporary Orthodontics. 5th ed. St Louis: MO Mosby; 2013.

16. Phillips C, Beal KNE. Self-concept and the perception of facial appearance in children and adolescents seeking orthodontic treatment. Angle Orthod. 2009; 79(1):12-6. [DOI: 10.2319/071307-328.1] [PMID: 19123700]

17. Bos A, Hoogstraten J, Prahl-Andersen B. Expectations of treatment and satisfaction with dentofacial appearance in orthodontic patients. Am J Orthod Dentofacial Orthop. 2003; 123(2): 127-32. [DOl: 10.1067/mod.2003.84] [PMID: 12594417]

18. Borelli C, Berneburg M. Beauty lies in the eye of the beholder? Aspects of beauty and attractiveness. J Dtsch Dermatol Ges. 2010; 8(5):326-30. [DOI: 10.1111/j.1610-0387.2009.07318_supp.x] [PMID: 20537001]

19. Mommaerts MY, Moerenhout BA. Ideal proportions in full face front view, contemporary versus antique. J Craniomaxillofac Surg 2011; 39(2):107-10. [DOI: 10.1016/j.jcms.2010.04.012] [PMID: 20542444]
20. Shell TL, Woods MG. Facial aesthetics and the divine proportion: a comparison of surgical and non-surgical class II treatment. Aust Orthod J. 2004; 20(2):51-63. [PMID: 16429875]

21. Jahanbin A, Basafa M, Alizadeh Y. Evaluation of the Divine Proportion in the facial profile of young females. Indian I Dental Research. 2008; 19(4):292-6. [PMID: 19075430]

22. Kiekens RMA, Maltha JC, Van't Hof MA, Kuijpers-Jagtman AM. Objective Measures as Indicators for Facial Esthetics in White Adolescents. Angle Orthod. 2006; 76(4):551-6. [DOI: 10.1043/0003-3219(2006)076[0551:OMAIFF]2.0.CO;2] [PMID: 16808558]

23. Scolozzi P, Momjian A, Courvoisier D. Dentofacial deformities treated according to a dentoskeletal analysis based on the divine proportion: are the resulting faces de facto divinely proportioned? J Craniofac Surgery. 2011; 22(1):147-50. [DOI: 10.1097/SCS.0b013e3181f6f9cc] [PMID: 21187759]

24. Baker BW, Woods MG. The role of the divine proportion in the esthetic improvement of patients undergoing combined orthodontic/ orthognathic surgical treatment. The Int J Adult Orthodon Orthognath Surg. 2000; 16(2):108-20. [PMID: 11482289]

25. Anić-Miloševic S, Lapter-Varga M, Šlaj M. Analysis of the soft tissue facial profile of Croatians using of linear measurements. I Craniofac Surg. 2008; 19(1):251-8. [DOl: 10.1097/scs.0b013e31815c9446] [PMID: 18216697]

Received: 16.08.2016 • Accepted: 14.11.2016 


\title{
Promena parametara anfasa nakon ortodontske terapije malokluzije II klase
}

\author{
Jovana Milutinović, Nenad Nedeljković \\ Univerzitet u Beogradu, Stomatološki fakultet, Klinika za ortopediju vilica, Beograd, Srbija
}

\begin{abstract}
KRATAK SADRŽAJ
Uvod Cilj ovog rada bio je da se antropometrijskim merenjem fotografija anfasa pacijenata pre i posle ortodontske terapije malokluzije II klase, 1. odeljenja, utvrde promene linearnih parametara i proporcija, kao i njihovo odstupanje od idealnih vrednosti.

Materijal i metod $U$ istraživanju su korišćene fotografije anfasa 50 pacijenata pre i posle ortodontske terapije. Pacijenti su podeljeni u dve grupe, od kojih je jedna lečena ekstrakcionom (fiksni aparati sa intermaksilarnim gumicama II klase), a druga neekstrakcionom (fiksni aparati sa fiksnim funkcionalnim Herbst aparatom) metodom terapije malokluzije II klase. Na fotografijama su, nakon iscrtavanja mekotkivnih tačaka, mereni linearni parametri: podela lica na horizontalne trećine, dužina i širina lica, kao i set linearnih proporcija koji su u odnosu idealnih proporcija.

Rezultati Dobijeni rezultati pokazali su da je kod obe grupe pacijenata došlo do promene u antropometrijskim parametrima srednje i donje trećine lica. Dobijena razlika bila je statistički značajna $($ Sig < 0,01). Kod obe grupe pacijenata dobijena je razlika u odnosu linearnih parametara prema setu idealnih proporcija, naročito u donjoj trećini lica, u kojoj se taj odnos približio idealnim vrednostima i proporciji $1: 1,618$.

Zaključak Pacijenti sa malokluzijama II klase, 1. odeljenja, odstupaju od idealnih vrednosti facijalnih proporcija, pogotovo u donjoj trećini lica. Nakon završene ortodontske terapije vrednosti antropometrijskih parametara u donjoj trećini lica se približavaju idealnim vrednostima, u obe grupe pacijenata.

Ključne reči: malokluzije II klase, antropometrija, facijalne proporcije
\end{abstract}

\section{UVOD}

Merenja lica i facijalne estetike su imala svoj razvojni put. U prošlom veku prvi od načina merenja facijalnog izgleda odnosio se pre svega na izgled mekotkivnog profila pacijenta.

$\mathrm{Na}$ telerendgenskim snimcima mereni su parametri mekotkivnog profila, dok je merenje parametara anfasa zapostavljeno zbog nemogućnosti dobijanja dobre vidljivosti mekotkivnih struktura na posteroanteriornim snimcima glave. Ovi snimci su indikovani za analize skeletnih struktura, manje dentalnih, ali nisu izbor za analizu mekih tkiva. Iako je poznato da su mekotkivne analize opisane od autora još u prošlom veku našle svoju primenu u ortodontskoj dijagnostici i pokazale da su jako korisne, ne mogu nam pomoći u određivanju šireg pojma facijalne lepote [1]. U prošlosti, nekoliko analiza mekih tkiva lica su razvijene da bi se merile facijalne pozicije $[2,3]$. Ove rane mekotkivne analize nisu bile kombinovane sa kliničkom procenom i nijedna od njih nije istraživala sve važne elemente lica. Nedavno, facijalni balans, dijagnoza lepote i planiranje tretmana su unapređeni kombinacijom kliničke analize lica i mekotkivne kefalometrije [4].

Može se reći da trenutno ne postoji nijedna kefalometrijski bazirana trodimenzionalna analiza mekotkivnih parametara koja bi nam tačnije predstavila smernice za facijalnu lepotu i atraktivnost. Sama metoda ortodontske terapije u cilju ispravljanja anomalije (koja je kako dentoalveolarna, tako i skeletna, i kao takva obuhvata i meka tkiva koja određuju izgled lica) ne menja bitno facijalni izgled, tako da se odgovor mora potražiti u komparaciji izgleda pre i nakon terapije, ma koje vrste ona bila $[5,6]$.

Upravo zbog toga precizno i potpuno estetski opravdano pitanje promenjene percepcije facijalne privlačnosti nakon završene ortodontske terapije je merenje parametara anfasa na fotografijama pacijenta $[7,8]$.

Forma i sklad lica su direktno povezani sa idealnim proporcijama. Međutim, kada se govori o anfasu i proporcijama lica, danas je diskutabilno da li se približavanjem idealnim proporcijama sledstveno menja i percepcija lepote lica. Iako je u mnogim studijama dokazano da ove proporcije igraju ulogu u promeni atraktivnosti lica, rezultati se moraju gledati sa rezervom ukoliko poredimo isključivo rezultate ortodontske terapije $[9,10,11]$.

Cilj rada bio je da se antropometrijskim merenjem parametara i proporcija na fotografijama anfasa dve grupe pacijenata ispita koliko je odstupanje vrednosti parametara od idealnih proporcija, posebno u donjoj trećini lica, kao i da se ispita razlika u antropometrijskim linearnim parametrima lica pre i nakon završene ortodontske terapije.

\section{MATERIJAL I METOD}

U ovom istraživanju korišćene su anfas fotografije 50 pacijenata sa malokluzijom II klase, podeljenih na dve grupe. Prva grupa od 25 pacijenata je lečena ekstrakcionom metodom (fiksni aparati sa intermaksilarnim gumicama II klase) - slika 1a, a druga grupa od 25 pacijenata neekstrakcionom (fiksni aparati sa fiksnim funkcionalnim Herbst aparatom) metodom - slika 1 b.

$\mathrm{Na}$ fotografijama svakog pacijenta pre i posle terapije iscrtavane su tačke, a zatim su njihovim spajanjem dobijene linije na osnovu kojih su se određivali potrebni linearni parametri.

Tačke, odnosno facijalna obeležja, merena na fotografijama su: Ch (cheilion) - tačka koja se nalazi na samom uglu usana;

Lc (lateral canthus) - tačka koja se nalazi na spoljašnjem, odnosno unutrašnjem uglu oka, koja se može označiti i pojedinačnim tačkama:

Ln (lateral nose) - tačka na spoljnoj ivici nosnog krilca u visini vrha nosa, sa leve i desne strane;

Lchk (lateral cheek) - najlateralnija tačka obraza;

Ts (temporal soft tissue) - najlateralnija tačka na čelu u nivou obrva;

$\operatorname{Tr}$ (trichion) - početak kosmatog dela glave;

$\mathrm{N}$ (nasion) - tačka na prelazu gornje u srednju trećinu lica; 
Sn (subnasale) - tačka na granici donjeg dela nosa i gornje usne;

Sto (stomion) - tačka na granici gornje i donje usne;

Me (menton) - najniža tačka na bradi.

Na fotografijama anfasa su zatim mereni sledeći parametri:

\section{Horizontalne trećine lica (Slika 2):}

1) prva trećina od tačke trichion do tačke nasion (gornja trećina)

2) druga trećina od tačke nasion do tačke subnasale (srednja trećina)

3) treća trećina od tačke subnasale do tačke menton (donja trećina)
II.Dužine - proporcije linearnih parametara (Slika 3):
1) $\mathrm{Me}-\mathrm{Sto}$
2) Sto-Lc
3) $\mathrm{Me}-\mathrm{Ln}$
4) $\mathrm{Ln}-\mathrm{Tr}$

III. Dimenzije lica (Slika 4):

1) Trichion-Menton (dužina odnosno visina lica)

2) Lchk-Lchk (širina lica)

Nakon ucrtavanja tačaka i spajanja tačaka potrebnih za dobijanje odgovarajućih dužina, mere se proporcije. Za svaki od ovih parametara postoje idealne proporcije, tako da stvarna dužina različitih parametara nema nikakvu ulogu i samim tim je mogućnost greške svedena na minimum.

Horizontalne trećine lica treba da budu jednake, čeoni, nosni i vilični sprat treba da budu iste dužine na svakoj fotografiji ponaosob; dakle, porede se dužine i njihova jednakost pojedinačno na svakoj fotografiji, tako da stvarna dužina ovih parametara nema značaj, već samo njihov odnos. (Slika 2)

Gornji deo viličnog sprata lica, rastojanje između tačaka subnasale i stomion treba da bude $1 / 3$ ukupne dužine viličnog sprata lica, tj. rastojanja između tačaka subnasale-menton (Slika 5).

Odnos dužina rastojanja menton-stomion i stomion-lateral canthus treba da bude $1: 1,618$ (Slika 3).

Odnos dužina rastojanja menton-lateral nose i lateral nosetrichion treba da bude $1: 1,618$ (Slika 3).

Ako je širina lica odnosno rastojanje između dve tačke lateral cheek (lchk) 1, dužina lica, tj. rastojanje između tačaka trichion i menton treba da bude 1,618 (Slika 5).

\section{REZULTATI}

Rezultati ovog istraživanja su prikazani u tabelama 1 i 2.

$\mathrm{U}$ tabeli 1. prikazani su rezultati pre i posle terapije za obe grupe pacijenata, i statistički značajna razlika ( $\mathrm{Sig}=<0,01)$ dobijena je za parametre srednje i donje trećine lica ( $\mathrm{N}-\mathrm{subN}$ i subN-Me) kod obe grupe pacijenata. Odnos srednje i donje trećine lica je promenjen, i u prvoj grupi pacijenata posle terapije iznosio je 0,9 , a u drugoj grupi pacijenata 0,92 .

U tabeli br. 2 prikazani su parametri dužina. Za parametre Me-Ln i Tr-Me dobijena je statistički značajna razlika u vrednostima pre i posle terapije ( $\mathrm{Sig}=<0,01$ ).Kada uporedimo odnos srednje i donje trećine lica, primećujemo da je pre terapije on iznosio 1,1 (dužina $\mathrm{N}$-subN bila je $46,77 \mathrm{~mm}$, a dužina
subN-Me 52,20 mm), dok je posle terapije taj odnos iznosio 0,9 (dužina N-subN je 43,72 mm, a dužina subN-Me 48,44 mm). U prvoj grupi pacijenata odnos dužina Me-Ln i Ln-Tr je pre terapije iznosio $1: 1,36$ (dužina Me-Ln bila je $61,93 \mathrm{~mm}$, a dužina Ln- Tr 84,38 mm), dok je posle terapije ovaj odnos iznosio 1 : 1,5 (dužina Me-Ln iznosila je 55,71 mm, a dužina Ln-Tr 83,76 $\mathrm{mm})$.U drugoj grupi pacijenata odnos ova dva parametra je pre terapije iznosio 1,45 (dužina Me-Ln bila je 48,72 mm, a dužina Ln-Tr 70,72 mm), dok je nakon terapije ovaj odnos promenjen i iznosi 1,62 (dužina Me-Ln je nakon terapije iznosila 48,57 mm, a dužina $\operatorname{Ln}-\operatorname{Tr} 78,77 \mathrm{~mm})$.

\section{DISKUSIJA}

Analiza anfasa i mekotkivnog profila ispitanika i poređenje rezultata sa standardnim, prosečnim vrednostima, neophodna je u svim specijalnostima medicine i stomatologije koje mogu, u bilo kojoj meri, menjati karakteristike - obeležja lica [12, 13, 14]. Takve su npr. ortognatska i plastična hirurgija, ortodoncija, stomatološka protetika. Podrazumeva se da je važno, kada kliničar pokušava da poboljša izgled pacijenta, to da li će se njegova mentalna slika poboljšanja poklopiti sa slikom samog pacijenta, ali i njegove porodice i, naravno, širokog kruga poznanika i šire javnosti.

Razmišljanje o individualnoj proceni lepote kao merodavnoj pa do varijacija kolektivnih shvatanja koja se menjaju zajedno sa modnim trendovima mogu se pronaći u radovima mnogobrojnih autora [15]. Naravno, podrazumeva se da ortodonti i kolege hirurzi dele isto mišljenje o tome šta bi trebalo da budu objektivni klinički ciljevi koji se odnose na poboljšanje pacijentovog izgleda $[16,17]$.

U ovom istraživanju merili su se parametri anfasa koji nam govore kako o simetriji i prisustvu pravila podele lica na jednake delove, tako i o usklađenosti proporcija lica i, već pomenutih, idealnih proporcija. Kao što smo naglasili, lepota je u načelu nemerljiva stvar i nalazi se u oku posmatrača, tako da je kvantitativno i numeričko poređenje parametara dvaju različitih grupa pacijenata izostalo iz objektivnih razloga [18].

Gornja, srednja i donja trećina lica bi trebalo kod usklađenog, harmoničnog lica da budu usaglašene, u odnosu 1:1. Donja trećina lica se još može podeliti pomoću linije koja prolazi kroz tačku dodira gornje i donje usne - stomion, na gornji i donji deo, koji stoje u odnosu 2:1 [19].

U grupi pacijenata kod kojih su izvršene ekstrakcije statistički značajna razlika dobijena je za parametre srednje i donje trećine lica. Međutim, kao što je već pomenuto, sama dužina i promena vrednosti dužine parametara nam ne znači mnogo dok ne poredimo njihov međusobni odnos. Zanemarujući iznose u milimetrima, i posmatrajući odnos ovih parametara, dolazimo do zaključka da se donja trećina lica, ili donji sprat povećao u odnosu na srednji sprat nakon završene ortodontske terapije. Razlog i objašnjenje treba tražiti u promeni parametara vertikalnog rasta, i povećanja vertikalne dimenzije usled primene intermaksilarnih gumica II klase. Međutim, posmatrajući ove vrednosti i poredeći ih sa zlatnim proporcijama, odnosno idealnim, jednakim odnosom trećina lica, možemo konstatovati da su ovi parametri jednako bliski zlatnim proporcijama bili i pre i posle terapije, te da razlika ne može biti opisana kao približavanje idealnim vrednostima i promeni fa- 
cijalne atraktivnosti koja se time objašnjava. Naravno, razlika je prisutna u samom kliničkom nalazu i u oku posmatrača. Do istih rezultata došli su i Shell i sar. [20], koji su upoređivali zlatne proporcije kod pacijenata sa II klasom malokluzija, koji su lečeni ili aktivatorom, tj. fiksnim funkcionalnim aparatom $\mathrm{u}$ periodu rasta, ili nakon završenog rasta lečeni fiksnim aparatom i ortognatskom hirurgijom. Upoređivana je i povezanost zlatnih proporcija sa percepcijom facijalne atraktivnosti, što je dodatno potvrdilo konstataciju da je diskutabilno to koliko se sama promena načinjena ortodontskom terapijom, iako menja izgled pacijenata, može poistovetiti sa približavanjem idealnim proporcijama lica [21].

U grupi pacijenata lečenih neekstrakcionom metodom, poredeći parametre horizontalne podele lica na jednake trećine, dobijena je statistička značajnost za parametar Tr-N. Kako se značajno promenio parametar gornje trećine lica, moramo utvrditi i tumačiti koji je novonastali odnos ovakve podele lica na trećine i da li on utiče na promenu percepcije pacijentovog lica u skladu sa mogućim približavanjem zlatnim proporcijama. I kod ove grupe pacijenata dobijen je sličan nalaz promene odnosa donje i srednje trećine lica u odnosu na gornju. Naime, prvobitni odnos od 1,1 je smanjen na 0,92 , što se tumači, kao i kod ekstrakcione grupe pacijenata, blagom promenom vertikalne dimenzije donje trećine lica [22].

Odnos pojedinih dužina i njihovo približavanje idealnim proporcijama određen je numerički, 1 na prema 1,618. Odnos dužina Me-Ln i Ln-Tr je pre terapije iznosio 1 : 1,36, dok je posle terapije ovaj odnos iznosio $1: 1,5$. Kako je idealan racio 1 : 1,618 , primećujemo da je nakon terapije međusobni odnos ovih parametara malo bliže idealnim vrednostima, usled promene parametra Me-Ln, koji označavaju dužinu donjeg dela lica i entiteta koji se menjaju tokom ortodontske terapije.

Ako posmatramo parametar Tr-Me, odnosno dužinu lica, iako je dobijena značajna promena, odnos dužine i širine lica, koji bi trebalo da odgovara zlatnom odnosu $1: 1,618$, neznatno je promenjen. Naime, odnos dužine (Tr-Me) i širine (lchk-lchk) lica je pre terapije iznosio 1,47, a nakon terapije 1,45. Kako su ovo vrednosti koje govore o širem aspektu izgleda anfasa i mogu se povezati sa oblikom lica, očekivano je da se percepcija izgleda u ovom segmentu neće puno promeniti nakon terapije.

U grupi parametara dužina lica određenih idealnim proporcijama, kod pacijenata lečenih fiksnim funkcionalnim aparatom bez ekstrakcije, statistički značajna razlika dobijena je za pa- rametar dužine Ln-Tr, koji se zajedno sa parametrom Me-Ln odnosi u vidu zlatnih proporcija. Odnos ova dva parametra je pre terapije iznosio 1,45 , dok je nakon terapije ovaj odnos promenjen i iznosi 1,62, što praktično predstavlja dostizanje idealnog odnosa između ova dva parametra. Dakle, možemo reći da je u ovoj grupi pacijenata došlo do postizanja idealnih proporcija u odnosu dva parametra, od kojih je jedan direktno povezan sa rezultatom ortodontske terapije, odnosno novim položajem brade i tačke Menton (koja u analizi parametara anfasa predstavlja najnižu tačku na bradi). Ovi rezultati su u skladu sa istraživanjem Scolozzija i sar. [23] koji su dobili značajno približavanje idealnim proporcijama nakon završene terapije za isti parametar u donjoj trećini lica.

Baker i sar. [24] vršili su ispitivanja povezanosti idealnih facijalnih proporcija nakon ortodontsko-hirurške terapije sa percepcijom atraktivnosti, uzimajući pritom u obzir i udaljene entitete lica koji utiču na sveukupni utisak lepote lica. Koristeći anketu, dolaze do rezultata koji govore o signifikantnom napretku i poboljšanju facijalne atraktivnosti, ali bez stroge povezanosti sa približavanjem, odnosno udaljavanjem od vrednosti idealnih, zlatnih proporcija. Oni preporučuju upotrebu ove metode merenja kao dopunsku, pomoćnu uz ostale kefalometrijske i antropometrijske analize.

Očekivano, ortodontska terapija malokluzija II klase, bez obzira na metod kojim je završena, ograničeno utiče na promenu parametara anfasa, a samim tim na približavanje ovih vrednosti idealnim, zlatnim proporcijama. Međutim, značajnije promene se dešavaju na mekotkivnom profilu, tako da je merenje ovih parametara na profilnim fotografijama predstavljalo srž mnogobrojnih istraživanja vezanih za ovu tematiku, i kao takvo predstavlja neizostavnu dopunu kompletne analize mekotkivnih facijalnih parametara [25].

\section{ZAKLJUČAK}

Antropometrijskim merenjem linearnih parametara i proporcija na fotografijama anfasa može se zaključiti da pacijenti sa malokluzijama II klase, 1. odeljenja, odstupaju od idealnih vrednosti facijalnih proporcija, pogotovo u donjoj trećini lica. Nakon završene ortodontske terapije, vrednosti antropometrijskih parametara u donjoj trećini lica se približavaju idealnim vrednostima, u obe grupe pacijenata. 